\title{
Correction to: Leaf age is important for assessment of resistance in chrysanthemum against Frankliniella occidentalis
}

\author{
Sina Alexandra Rogge ${ }^{1}\left[\right.$ (D) Rainer Meyhöfer $^{1}$ (]) \\ Published online: 19 October 2021 \\ (c) Deutsche Phytomedizinische Gesellschaft 2021

\section{Correction to: \\ Journal of Plant Diseases and Protection (2021) 128:511-516} \\ https://doi.org/10.1007/s41348-020-00402-1
}

The article: Leaf age is important for assessment of resistance in chrysanthemum against Frankliniella occidentalis, written by Sina Alexandra Rogge · Rainer Meyhöfer was originally published electronically on the publisher's internet portal (currently SpringerLink) on 12 November 2021 without open access.

With the author(s)' decision to opt for Open Choice, the copyright of the article changed on 30 October 2021 () The Author(s) 2021 and the article is forthwith distributed under the terms of the Creative Commons Attribution 4.0 International License (http://creativecommons.org/licenses/ by/4.0/), which permits use, duplication, adaptation, distribution and reproduction in any medium or format, as long as you give appropriate credit to the original author(s) and the source, provide a link to the Creative Commons license and indicate if changes were made.

Open Access This article is distributed under the terms of the Creative Commons Attribution 4.0 International License (http://creativecommons.org/licenses/by/4.0/), which permits unrestricted use, distribution, and reproduction in any medium, provided you give appropriate credit to the original author(s) and the source, provide a link to the Creative Commons license, and indicate if changes were made.

The original article was corrected.

Open Access This article is licensed under a Creative Commons Attribution 4.0 International License, which permits use, sharing, adaptation, distribution and reproduction in any medium or format, as long as you give appropriate credit to the original author(s) and the source, provide a link to the Creative Commons licence, and indicate if changes were made. The images or other third party material in this article are included in the article's Creative Commons licence, unless indicated otherwise in a credit line to the material. If material is not included in the article's Creative Commons licence and your intended use is not permitted by statutory regulation or exceeds the permitted use, you will need to obtain permission directly from the copyright holder. To view a copy of this licence, visit http://creativecommons.org/licenses/by/4.0/.

Publisher's Note Springer Nature remains neutral with regard to jurisdictional claims in published maps and institutional affiliations.
The original article can be found online at https://doi.org/10.1007/ s41348-020-00402-1.

Sina Alexandra Rogge

rogge@ipp.uni-hannover.de

1 Institute of Horticultural Production Systems, Section Phytomedicine, Gottfried Wilhelm Leibniz Universität Hannover, Herrenhäuser Str. 2, 30419 Hannover, Germany 